Status Report 2016-2019

\title{
Hydrological Modeling in India
}

\author{
RIDDHI SINGH ${ }^{1}$, VIMAL MISHRA ${ }^{2}$, BALAJI NARASIMHAN ${ }^{3}$, SUBIMAL GHOSH $^{4}$, ANUPMA \\ SHARMA $^{5}$, SUBHASISHA DUTTA ${ }^{6}$ and P P MUJUMDAR ${ }^{7, *}$ \\ ${ }^{1}$ Indian Institute of Technology, Bombay, India \\ ${ }^{2}$ Indian Institute of Technology, Gandhinagar, India \\ ${ }^{3}$ Indian Institute of Technology, Madras, India \\ ${ }^{4}$ Indian Institute of Technology, Bombay, India \\ ${ }^{5}$ National Institute of Hydrology, Roorkee, India \\ ${ }^{6}$ Indian Institute of Technology, Guwahati, India \\ ${ }^{7}$ Indian Institute of Science, Bangalore, India
}

(Received on 20 August 2019; Accepted on 04 September 2019)

\begin{abstract}
Human alteration of the natural environment continues nearly unabated in many parts of the world. This has resulted in exploitation of natural resources including water, over and above their limits of natural replenishment. Therefore, the International Association of Hydrologic Sciences (IAHS) has dedicated the decade 2013-2022 to explore the interactions between human society and hydrology. Due to its hydro-climatic and socio-economic diversity, India is a microcosm of the world where observations pertaining to physical hydrology as well as socio-hydrology can be made to develop generalizable insights. This has enabled a number of studies in the last few years advancing surface and groundwater modeling, process understanding, use of satellite-based or low-cost sensing for model development or improvement, inclusion of anthropogenic influences in hydrologic models, and uncertainty estimation methods. Further research in these directions is expected to continue to enable better decision making for management of water resources.
\end{abstract}

Keywords: Modeling; Transformations; International Association of Hydrologic Sciences

\section{Introduction}

Rapid transformations in infrastructure and standards of living over the last few years have left India's water resources in a precarious position. Water managers are finding it difficult to cope with the pace at which these changes are occurring and several large scale projects are being implemented to deal with foreseeable long-term water scarcity as well as hydrologic extremes of floods and droughts. This situation warrants a simultaneous advancement in hydrologic sciences so that decisions related to water management are made on a sound footing. A large number of studies exploring different aspects of Indian hydrology have been carried out in the last decadewhose synthesis allows the hydrologic community to appraise previous advancements and carve a path for the future. To this end, Mondal et al.
(2016) provided a comprehensive assessment of advances in hydrologic science in India. This report builds on that effort and summarizes advances in hydrologic sciences since then. It is encouraging to see that a few thrust areas of research suggested by Mondal et al. (2016) have been actively researched, but some challenges still persist. This report highlights advances in surface and groundwater modeling, process understanding, application of satellite-based or low-cost sensing for model development or improvement, and methods to quantify uncertainty in predicted hydrologic variables. Studies span various spatio-temporal scales and have a sound coverage of the country geographically.

\section{Advances in Surface Water Modeling}

The International Association of Hydrologic Sciences

*Author for Correspondence: E-mail: ppmujumdar@gmail.com 
(IAHS) designated the decade from 2003-2012 for improving the science of Prediction in Ungauged Basin (PUB) (Sivapalan et al., 2003). This triggered a considerable amount of research interest in India due to challenges in data availability and accessibility within the country. The recent decade saw hydrologic data becoming available online from local (e.g. INDIAWRIS, BHUVAN) as well as from global sources (e.g. APHRODITE, GLOVIS, GRDC). Although hydrological observational networks have expanded and improved across India in the last decade under the National Hydrology Project (NHP), still there is a need to improve and strengthen the quantity and quality of observation network across the country. The water cycle is also impacted due to the rapidly changing human systems. The existing observational networks are not necessarily explicitly designed to monitor changes brought about by the society. Further, hydrological models also need to be improved upon to capture the connections and interactions between hydrology and society and their co-evolution. Hence, following decade of PUB, the scientific decade 20132022 is dedicated to developing a comprehensive framework to the two-way feedback between society and hydrology (Socio-hydrology) entitled "Panta RheiEverything Flows" (Montanari et al., 2013).

\section{Developments in Model Algorithms}

In order to make better use of gridded information from the satellite directly, the Space Application Centre (SAC), Ahmedabad has developed a satellite-based hydrological model (SHM) (Paul et al., 2019). SHM is a parsimonious model, runs on a $5 \mathrm{~km} X 5 \mathrm{~km}$ grid cell and has a modular structure. Grid-to-grid routing was implemented in the model based on the time variant spatially distributed direct hydrograph (SDDH) method and has been tested at the Kabini dam measurement site (Paul et al., 2018a). SHM model was applied to the Subarnarekha river basin and was subjected to a robust hierarchical operational testing scheme with different criteria. The results showed that the SHM model structure, forced by satellite based inputs, is capable of realistically simulating the hydrology under different geographical and climatological conditions that exist across the country.

Real-time implementations of hydrologic models are now being attempted for monitoring the hydrologic conditions of river basins for which accurate initial soil moisture settingis essential. Understanding the sensitivity of hydrologic simulations to initial soil moisture conditions is very limited in Indian river basins. However, this information is much needed for determining model spin-up requirements for operational hydrologic forecasts. Niroula et al. (2018) studied the effect of perturbations in initial soil moisture conditions on streamflow simulations during the summer monsoon season in the Ganga River basin using VIC. The study showed that streamflows converge quickly for high rainfall years as well as for wet spells within a season. The convergence takes longer for regions with low rainfall, during break period and in regions with deeper soil layers. The Ganga River basin showed high spatial variations in convergence time due to its highly varying climatic regimes and soils. Hence, model spin-up time needs to be chosen carefully for such large basins to overcome the errors in initial soil moisture. Surface layer soil moisture data assimilation described later (Patil and Ramsankaran, 2017; Patil and Ramsankaran, 2018) could have the potential to reduce the model spin-up time and needs to be explored in future research.

\section{Application of Existing Models}

There are numerous applications of existing hydrologic models to Indian river basins. Commonly used hydrological models and their recent applications are being discussed here.

Variable Infiltration Capacity (VIC) model is a semi-distributed macroscale hydrologic model that solves water and energy balance equations at each grid cell. It is a physically-based model that can be coupled with climate models. Shah and Mishra (2016) used the VIC model to observe changes in hydroclimatic variables in the Indian sub-continental basins at long time scales. Recently, Hengade and Eldho (2016) applied the VIC model on Ashti Catchment (sub-catchment of Godavari Basin in India) to assess the impacts of LULC changes and rainfall trends on hydrological variables. Additionally, Chawla and Mujumdar (2015) employed the VIC model to separate the impacts of land use and climate change in the upper Ganga river basin. Srivastava et al. (2017) applied the water-budget method of the VIC-3L land surface model in the Kangsabati River Basin in eastern India to estimate evapotranspiration 
(ET) indirectly using the Penman-Monteith (PM) equation. More recently, Shah et al. (2019) applied the VIC model in India to estimate the role of irrigation on water and energy budgets. Other than water budget estimates, the VIC model has also been applied to estimate climate change impacts on hydropower in India (Ali et al., 2018).

Other than the VIC model, Noah and Community Land Model (CLM) have been used to study land surface hydrology in India. Noah is a land surface model (LSM) that simulates land-atmosphere interaction processes. It has a 1-layer canopy, 3-layer snow, and 4-layer soil as its major components. The Noah LSM has been used for soil moisture assimilation over Indian Subcontinent (Nair and Indu, 2016). The Community Land Model (CLM) represents various physical, chemical and biological land surface processes within the Community Earth System Model (CESM). Mishra et al. (2016) and Asoka et al. (2017) used an ensemble of VIC, NOAH, CLM, and MOSAIC LSMs available from the Global Land Data Assimilation System (GLDAS) for surface water storage estimation (sum of soil moisture, surface water, and canopy storage). Soil moisture was simulated from three LSMs (VIC, NOAH, and CLM) and agricultural drought events over India from 1951 to 2015 were reconstructed by Mishra et al. (2018). Kumar et al. (2017b) used the CLM Crop version 4 (CLM4) to simulate the land surface temperature (LST). Irrigation and urban biome can be incorporated into a grid cell in this model to identify the impact of irrigation. Coupling of CLM3.5 with Regional Climate Model (RegCM4) showed better skill in simulating Indian Summer Monsoon (ISM) (Maity et al., 2017).

Soil Water Assessment Tool (SWAT) is a physically based, semi-distributed and continuous time model that simulates the water and sediment yield in basins over long periods. It can be applied to small watersheds as well as large river basins. Mishra and Lilhare (2016) found satisfactory performance in simulating monthly streamflow for most of the selected basins in the Indian subcontinent using the SWAT model. By using SWAT with a unique combination of slope, soil, and land cover classes, Pandey et al. (2017) estimated various water balance components under future climatic scenarios. Goyal et al. (2018) evaluated the performance of SWAT in two different catchments under different resolution ( $30 \mathrm{~m}$ to $300 \mathrm{~m}$ ) of Digital
Elevation Model (DEM) from three sources namely SRTM, ASTER, and CartoDEM. SWAT was used for seasonal water budget analysis in the Betwa river basin (Suryavanshi et al., 2017), and for runoff and sediment yield prediction in Ken basin of Central India (Himanshu et al., 2017). Anand et al. (2018a) used SWAT to study trend in streamflow in Ganges basin.

HEC-HMS (Hydrologic Engineering CentreHydrologic Modelling System) can be used for both continuous and event-based hydrologic modelling. The model simulates precipitation-runoff processes within watersheds and is capable of simulating runoff at daily, monthly, and seasonal time scales. Mandal and Chakrabarty (2016) analysed different hydraulic models to detect flash flood probability using HECRAS and HEC-HMS software. MIKE SHE is a deterministic, distributed and physically based integrated catchment model capable of simulating surface water and groundwater interactions along with other hydrological processes. An integrated hydrologic model (MIKE SHE/MIKE 11) was used to evaluate the availability of groundwater and surface water and the effects of the future expansion of irrigated agriculture in a semi-arid watershed (Sishodia et al., 2017). Storm Water Management Model (SWMM) is a dynamic simulation rainfall-runoff modeloften used forstudying flood in urban areas. Bisht et al. (2016) designed a systematic drainage system using MIKE URBAN and SWMM model. 2D MIKE URBAN model overcomes the shortcomings of the 1D SWMM model for flood simulation and inundation. Rai et al. (2017) developed a GIS-based SWMM model to simulate streamflow for flood modelling in the Brahmani river delta.

\section{Incorporating Anthropogenic Interventions}

Rapid increases in urbanization, industrialization, and agricultural expansion over the last few decades have likely left palpable imprints on the water resources of the country. Consequently, several studies in the last few years explore methods to quantify the impact of anthropogenic interventions on various hydrologic fluxes. Most studies use a combination of hydrologic models, climate change scenarios, and socioeconomic scenarios to assess how human interventions may affect long-term water availability or likelihood of floods and droughts (Anand et al., 2018b; Mittal et al., 2016; Wagner et al., 2016; Zope et al., 2016). 
Wagner et al. (2016) assessed the joint impact of climate and land use change in medium sized Mula and Mutha River catchments draining the city of Pune. They found that the impact of land use change is evident in streamflow simulations of smaller sub-basins but not at the basin scale. Using the SWAT model, Mittal et al. (2016) assessed the impact of climate change and dam construction on different indicators of hydrologic alteration such as frequency, timing, and duration of high and low flows for the Kangsabati River. They found that the combined effect of climate change and dam construction is significantly greater than the individual impact of dam or climate change. Zope et al. (2016) performed an event-based analysis of flood peaks and flood runoff volumes for a small urban catchment in Mumbai and reported a marginal increase in both variables for floods of 2-yr and 100yr return periods despite a $74.84 \%$ increase in the built-up area of the catchment over the period of analysis. Dey and Mishra (2017) provide a comprehensive review of different methods that can be used to separate the impacts of climate change and human interventions on hydrologic fluxes. Madhusoodhanan et al. (2016) provide a review of challenges in assessing the joint impact of climate and other anthropogenic interventions on water resources of the country, highlighting the need to develop fineresolution datasets for both hydro-meteorological and water use data.

\section{Advances in Groundwater Modeling}

Groundwater is a significant source of domestic and irrigation water in many parts of India. As the demand for water rises, this invisible resource is diminishing in both quality and quantity. This section discusses recent advances in the estimation of groundwater depletion rates, coastal groundwater modeling, modeling of water quality and groundwater management.

\section{Estimating Groundwater Depletion Rates}

Population growth and climate extremes (e.g., droughts) have contributed to increased groundwater withdrawals, which has led to significant groundwater depletion (GWD) in many areas. Environmental impacts of GWD are diverse such as decrease in baseflows resulting in drying-up of wetlands and rivers, land subsidence, saltwater intrusion, and declining water supplies. Traditional approaches for assessing GWD rely on groundwater level data from wells that are relatively sparse or inaccessible in many aquifers, preventing a consistent assessment of GWD over major aquifers that are extremely important for agricultural production.

The Northwest India Aquifer (NWIA) has been shown to have the highest GWD rate globally, threatening crop production and sustainability of groundwater resources. Long et al .(2016) assessed GWD in the three-state region (i.e., Punjab, Haryana \& Delhi, and Rajasthan with a total area of 438,296 $\mathrm{km}^{2}$ ) of NWIA. GWD rates were evaluated over the NWIA using a variety of approaches, including constrained forward modeling resulting in a GWD rate of $3.1 \pm 0.1 \mathrm{~cm} / \mathrm{a}$ (or $14 \pm 0.4 \mathrm{~km}^{3} / \mathrm{a}$ ) for Jan 2005 Dec 2010, consistent with the GWD rate $(2.8 \mathrm{~cm} / \mathrm{a}$ or $12.3 \mathrm{~km}^{3} / \mathrm{a}$ ) from groundwater level monitoring data. As the quality of GRACE data and related processing techniques improve, GRACE satellites will become more valuable in assessing GWD.

Using multiple data sources (GRACE, well observations, PCR-GLOBWB model, precipitation, and sea surface temperature) and methods such as regression and dominance analysis, Asoka et al. (2017) concluded that long-term changes in monsoon precipitation are driving groundwater storage variability in most parts of India either directly by changing recharge or indirectly by changing abstraction. It was found that groundwater storage has declined in northern India at the rate of $2 \mathrm{~cm}$ $\mathrm{yr}^{-1}$ and increased by 1 to $2 \mathrm{~cm} \mathrm{yr}^{-1}$ in southern India between 2002 and 2013.

\section{Coastal Groundwater Modeling}

Indiscriminate and unplanned groundwater withdrawal for fulfilling the growing freshwater needs of coastal regions leads to the problem of saltwater intrusion. Numerical modelling for variable density flow and transport is a useful tool in helping hydrologists to understand and predict how saltwater intrusion occurs in coastal aquifers. SEAWAT module in MODFLOW based on finite differencescheme has been used by various researchers to investigate the saltwater intrusion process in coastal aquifers in India (Dunlop et al., 2019; Gopinath et al., 2016; Lathashri and Mahesha, 2015; Maheswaran et al., 2016; Surinaidu et al., 2016). 
Besides numerical models, data-based models, such as the artificial neural network (ANN), support vector machine (SVM), genetic programming (GP) and extreme learning machine (ELM), have also been utilized to approximate 3D variable density flow and transport processes in coastal aquifers. Yadav et al. (2018) used SEAWAT to generate data required for the training and testing of the data-based models. Four data-based models (ANN, SVM, GP, and ELM) were considered as proxy simulators to simulate variable density flow and transport. The selected models were also compared based on their computational ability, and results showed that ELM was the fastest technique taking just $0.5 \mathrm{~s}$ to simulate the dataset; however, SVM was the most accurate, with Nash-Sutcliffe efficiency $\geq 0.95$ and correlation coefficient $\geq 0.92$ for all the wells. Unlike process-based models, SVM and ELM do not require basin information and other physical parameters in the modelling process. Thus, a databased model such as SVM and ELM can also be utilized for saltwater intrusion modelling provided the training dataset is large enough so that the model architectures can capture the involved complexities adequately.

\section{Modeling of Groundwater Quality}

Groundwater contamination has serious effects as it persists for a long time due to the high residence time of groundwater. The unsaturated zone acts as a conduit for transport of contaminants to the groundwater. Beegum et al. (2018) developed a modified unsaturated flow and transport package and linked it to the groundwater flow model MODFLOW and groundwater solute transport model MT3DMS. In addition to water flow in the vadose zone, the new package can also simulate solute transport involving many biogeochemical processes and reactions, including first-order degradation, volatilization, linear or nonlinear sorption, one-site kinetic sorption, twosite sorption, and two-kinetic sites sorption. Sharma et al. (2016) developed a numerical model for the mobile-immobile phase advective-dispersive transport equation including equilibrium sorption and the firstorder degradation. The numerical model was also used to simulate experimental breakthrough curves (BTCs) for transport of chloride and fluoride through heterogeneous soil column using constant, linear, and exponential distance-dependent dispersion models. It was shown that the behavior of the concentration profile produced with a constant dispersion model is similar to the distance-dependent dispersion model.

Radioactive wastes are one of the potential sources of radiation causing risk to the environment and human health. Recent studies have concluded that "geological isolation" is the safest long-term option for storing high level radioactive waste. Thus, waste disposal facilities aim to isolate these wastes from the environment. A fully implicit finite difference numerical model was developed byBagalkot and Kumar (2016) to simulate two species radionuclide transport in a coupled single fracture-matrix system with variable fracture aperture and results so obtained were compared with a parallel plate model. Two distinct geometric profiles namely, sinusoidal and logarithmic have been used to capture the variation of aperture width. The dependence of advection, hydrodynamic dispersion, linear sorption, and matrix diffusion on aperture width was considered in the analysis of radionuclides transport. Geetha Manjari and Sivakumar Babu (2018) modelled the radionuclide transport from the barrier using FEFLOW, capable of simulating groundwater flow and contaminant transport problems in porous and fractured media. A three-dimensional domain with a decaying source concentration was modelled and the concentration was measured at different distances up to 50 and $200 \mathrm{~m}$ away from the source for short-lived (strontium $\left({ }^{90} \mathrm{Sr}\right)$, cesium $\left({ }^{137} \mathrm{Cs}\right)$ and long-lived radionuclides (carbon $\left({ }^{14} \mathrm{C}\right)$ and iodine $\left.\left({ }^{129} \mathrm{I}\right)\right)$. A code was developed using the built-in python interface of FEFLOW to run the simulations and make the model computationally efficient. The development of code using python interface bridged the deterministic FEM software with a probabilistic analysis.

Using an implicit finite difference scheme, Mohanadhas and Govindarajan (2018) developed a one-dimensional numerical model to describe the transport of Uranium ${ }^{238} \mathrm{U}$ and its progenies in the vadose zone from uranium tiling pond situated on the soil surface. The numerical results show that the ${ }^{238} \mathrm{U}$ and its progenies are migrating up to a depth of $90 \mathrm{~m}$ and $800 \mathrm{~m}$ after 10 years in silty and sandy soil, respectively. Essentially, silt may reduce the risk of contamination in the groundwater for a longer time span and at the deeper depths. In general, a coupled effect of sorption and hydro-geological parameters (soil type, moisture context and hydraulic conductivity) 
decides the resultant uranium transport in the subsurface environment. Similarly, Renu and Kumar (2016) developed a finite difference numerical model to simulate the transport of aqueous benzene concentration along a fracture in a saturated fracturematrix system. Wagh et al. (2018) employed the ANN model for prediction of nitrate concentration in groundwater of Kadava River basin, Nashik District, Maharashtra.

\section{Groundwater Management and Vulnerability Assessment}

Three broad methods can be used for assessing groundwater contamination risk: process-based models, statistical methods employing laboratory and site-specific data, and overlay and index methods that use the spatial representation of hydrogeologic features (Ahada and Suthar, 2018). The DRASTIC method uses several hydrogeological parameters to estimate aquifer vulnerability to pollution. Generally, DRASTIC employs seven hydrogeological factors within a GIS framework: depth to water table, net recharge, aquifer media, soil media, topography (slope), material comprising vadose zone, and hydraulic conductivity. These factors are weighted to arrive at a combined 'DRASTIC' index that indicates vulnerability. Applications of the DRASTIC method and its modifications include analyses by Ghosh and Kanchan (2016) for the Bengal alluvial tract; Kumar et al. (2016a) for Fatehgarh Sahib district in Punjab; Joshi and Gupta (2018)for Ajmer District in Rajasthan, and Karan et al. (2018) for Jharia Coalfield in Dhanbad district of Jharkhand. Using the analysis conducted for the cultivable belt of Malwa in Punjab, Ahada and Suthar (2018) reported that parts of aquifers of eastern and western Malwa region are at greater risk of contamination. On further analysis, it was noticed that two factors: vadose zone and depth to groundwater table determine the aquifer vulnerability in the Malwa region.

Several studies attempt correlated groundwater quality as indicated by the well data and the DRASTIC-predicted vulnerability index (Ghosh and Kanchan, 2016; Karan et al., 2018). Ghosh and Kanchan (2016) found that the DRASTIC vulnerability index and observed arsenic concentrations in groundwater together indicated that the eastern portion of Bengal alluvial tract is more susceptible to arsenic pollution. However, individual factors that are used to estimate the DRASTIC index were found to have varying degrees of correlation with observed arsenic concentrations, indicating that some factors are more important than others when assessing vulnerability w.r.t specific contaminants. Kumar et al. (2016a) found that higher vulnerability zones as indicated by the DRASTIC index were generally related to the high groundwater pollution. However, the contaminants responsible for poor groundwater quality varied across the high vulnerability zones. They, therefore, recommend that additional information related to anthropogenic activities such as land cover types, urban settlements, mining and exploration activities, etc. should also be incorporated in the DRASTIC framework to enable site-specific applicability.

Problems pertaining to groundwater management range from estimation of aquifer response to changes in recharge or pumping rates to conjunctive use of surface and groundwater.Sahoo and Jha (2017) developed a conceptual model of groundwater flow for the multi-layered aquifer system of the Kushabhadra-Bhargavi inter-basin in the Mahanadi River delta. Using this model, they evaluated the response of the aquifer system to various pumping scenarios and found that the impact of changes in pumping rates was greater for the confined aquifer when compared with that of the unconfined aquifer. They also found that multi-layered aquifers can show a nonlinear response to changes in recharge and pumping rates, with various layers displaying quite different behavior. This should be considered while planning for management strategies of such aquifers. Using a similar model-based analysis, Sashikkumar et al. (2017) explored the impact of artificial recharge on groundwater levels in the Kodaganar River basin in Dindigul district of Tamil $\mathrm{Nadu}$. They found significant spatial variations in response to groundwater levels to artificial recharge structures.

\section{Advances in Process Understanding}

\section{Land-Atmosphere Feedback}

Analysis of feedback processes between land and atmosphere is still a neglected area for hydrometeorological analyses in the Indian sub-continent. 
Monsoon circulations are traditionally believed to be associated with large scale circulations (Kumar et al., 1999; Saji et al., 1999) and among local factors aerosols have got significant attention(Bollasina et al., 2011; Sarangi et al., 2017). There has been growing evidence (Pathak et al., 2017a; Pathak et al., 2017b) on the feedback from hydrologic processes to monsoon rainfall specifically the Indian Summer Monsoon Rainfall (ISMR). The existing literature on land-atmosphere interactions emphasizing feedback processes may be classified into two broad categories:

i. quantification of moisture supply from land sources using backward trajectory approach, and,

ii. use of coupled land-atmosphere simulations to perform multiple experiments.

The literature on the backward trajectory approach uses a modelling technique known the dynamic recycling modelling. The atmospheric moisture over a region has two sources (Fig. 1). The first one is the advective moisture coming from distant sources, mostly the oceans. The other fraction is through evapotranspiration (ET) from land, known as recycled moisture and the associated precipitation fraction is known as recycled precipitation (Dominguez et al., 2006; Eltahir and Bras, 1996). The contribution of this recycled moisture to the precipitation in the same region is known as "Precipitation Recycling" and it is characterized by the ratio of recycled

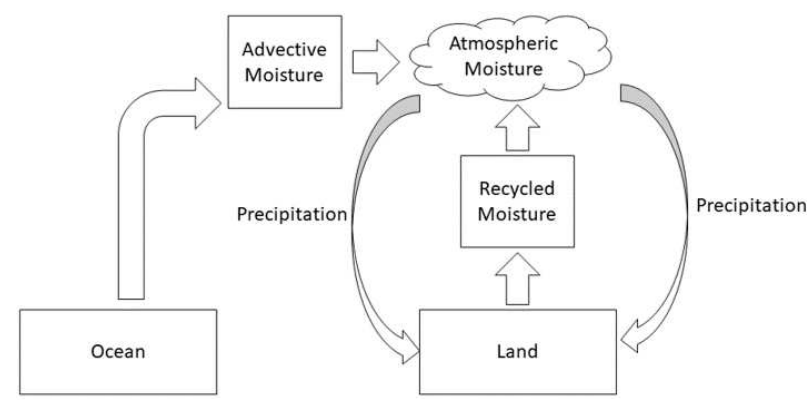

Fig. 1: Conceptualization of recycled and advective moisture

precipitation to the total precipitation.

Pathak et al. (2017b) found that recycled precipitation not only affects the seasonal rainfall but also its intraseasonal variations. Intraseasonal oscillations of Indian summer monsoon rainfall is associated with the northward propagation of high and low rainfall bands resulting in active and break periods. This also results in a north-south asymmetry of rainfall. Pathak et al. (2017a) showed that along with this north-south asymmetry, there also exists an east-west asymmetry that can be attributed to the recycled moisture. This land contribution mostly comes from the vegetation over the Gangetic basin.

The approach related to coupled landatmosphere simulations involves simulation of the water cycle with coupled models either at the global or regional scale. Regional simulations have been performed by Paul et al. (2016) using the Weather Research and Forecasting (WRF) model coupled with CLM.They found that the changing pattern of monsoon is sensitive to the land use land cover changes. For example, deforestation along with an increase in cropland area results in a declining trend of monsoon and this is mostly restricted over the North East India and the Ganga basin. Paul et al. (2018b) further found that the moisture generated from the vegetation of Western Ghats contributes a significant fraction of rainfall in the state of Tamilnadu during the summer monsoon season.

Though land processes play a major role in monsoon rainfall, the operational monsoon model in India, the Climate Forecast System Version 2 (CFSv2) still does not consider land processes adequately (Sahana et al., 2018). CFSv2 also has a very high dry bias over the Gangetic basin, i.e., it underestimates the rainfall amount. Devanand et al. (2018) hypothesized that poor representation of land processes is responsible for the dry bias in CFSv2. Devanand et al. (2018) performed regional coupled land-atmosphere simulations using WRF-CLM with CFSv2 boundary conditions and have found a significant decrease in the dry bias with improvements in the seasonal monsoon simulations. In the regional coupled framework, simulations of ET get significantly improved and produce high recycled precipitation. Further to this, a better representation of the Himalayas controls the circulation patterns and produces reliable estimates of monsoon rainfall.

One of the major limitations of the abovementioned studies is that they do not explicitly consider the irrigation over Indian cropland, which may affect significantly the water cycle. The irrigation practices are also different in India, for which improvisation of 
models is required. Consideration of India specific irrigation, analysing its impacts on monsoon rainfall and understanding the predictability of coupled processes dominated by feedback may be considered as a potential area for future research.

\section{Integrating Eco-Hydrological Processes}

The hydrological cycle and the biogeochemical cycle of the earth are highly interconnected. In the past 25 years, across the world, the earth science community has established Critical Zone Observatories (CZO) to study through detailed long-term observations, the impact of land-use changes and climate variability on the hydrological and biogeochemical fluxes of different ecosystems across spatiotemporal scales (Banwart et al., 2013). There is only one CZO located in India in Kabini, a subbasin of Cauvery. The specific aim of the Kabini CZO is to provide insights into the influence of climate variability and agriculture on water and biogeochemical cycles and has been monitored since 2003 (Sekhar, 2016). This has been a test bed for several studies related to a) soil moisture retrieval from Microwave remote sensing, b) algorithms to retrieve latent heat flux and ET estimation, c) retrieval of soil hydraulic properties, and d) development and testing of the groundwater model AMBHAS-GW (Sekhar, 2016). India with its diverse ecosystems due to its climatic variability, topographic and geographical setting in the tropics needs to have more CZOs to better understand the interactions and feedbacks due to landuse, climate and human interventions in different agro-climatic settings. Indian contributions to the Earth system science from such CZOs near the tropics could help considerably to improve process representations in hydrologic models and their reliability as tools for water resources planning and management.

\section{Hillslope Experiments}

The process of runoff generation in hillslopes is complex due to the requirement of detailed hillslope conditions for process conceptualization. Chouksey et al. (2017) attributed the influence of subsurface flow in the runoff process to soil and macropore characteristics in the Western Himalayan hillslopes. They developed an empirical hillslope hydrological model by observing runoff generation process using controlled rainfall simulation (drop size, velocity, kinetic energy, intensity ranges, uniformity and continuity of flow) over vegetated hillslopes and estimating vertical profile of soil macropore fraction, moisture variability and soil characteristics. A dye infiltration test on soil column for macropore fraction variability was also carried out. Chouksey et al. (2017) reported that for long duration rainfall, bottom soil layer at a depth of $600-1000 \mathrm{~mm}$ became permanently saturated with the passage of time. The results of Chouksey et al. (2017) highlight the importance of AMC and subsurface conditions on runoff generation processes. Furthermore, they also estimated surface runoff, subsurface runoff and soil/macropore storage components with high accuracy.

\section{Surfacewater Groundwater Interactions}

Mukherjee et al. (2018a) attributed the observed reduction in summer flows in lower reaches of Ganges River in the period 1999-2013 to nearly 59\% reduction in baseflow contributions from the Gangetic aquifers. They used a combination of in-situ and remotely sensed data along with numerical modeling techniques to quantify the interaction between the Gangetic aquifers and flow in different reaches of the river. Sahoo and Jha (2017) explored aquifer-river interaction using a conceptual model of the multi-layered aquifer system of the Kushabhadra-Bhargavi inter-basin in the Mahanadi River delta. They found that during the post-monsoon season the middle and lower reaches of the Kushabhadra and Bhargavi rivers recharge the adjoining aquifer $\left(4.41 \mathrm{Mm}^{3}\right)$, while the aquifer provides baseflow to the rivers $\left(0.85 \mathrm{Mm}^{3}\right)$ during pre-monsoon season. A similar analysis by Surinaidu et al. (2016) uses two physically-based models, SWAT, and MODFLOW, to simulate aquifer-stream interactions in the Ramganga sub-basin of the Ganges river basin. They use this semi-coupled modeling framework to assess the technical feasibility of conjunctive use of surface and groundwater in the Ganges river basin so that the aquifer itself can act as a storage unit, diminishing the need for large infrastructural investments in surface storages. They found that controlled pumping may help create subsurface storage in the aquifer, which combined with appropriate artificial recharge structures can simultaneously maintain groundwater levels. Although baseflow will be reduced in such a scenario unless additional natural recharge from rainfall is available. 


\section{Advances in Observations}

\section{Application of Remote Sensing Data}

In the present decade, understanding the link between Water, Energy and Nutrient cycles is of growing interest around the globe for sustainable hydroecological management practices. Especially in different agro-climatic regions in India, varying climate from tropical to temperate, Himalayan to plains and, rainforests to deserts has significant control over the hydrological processes at local and global scales. Moreover, growing anthropogenic activities and, interventions to the natural systems are prominent in the present day, showing significant impact on these cycles. Recent advancement in geo-spatial technologies and global satellite platforms provide synoptic information to understand and monitor the changes in such coupled cycles (Fig. 2). The availability of global data sets, GIS techniques, and, efficient data analysis algorithms have been helping researchers to analyze these cycles at different scales. Table 1 lists the recent research work carried for Indian River basins using advanced satellite data.

\section{Precipitation Estimates}

Precipitation plays an important role in the hydrological cycle and acts as a dominant source of water for all living beings. Accurate estimation of precipitation is crucial for agriculture dependent countries like India, where precipitation impacts socio-economic conditions of the society. Satellite derived rainfall estimates has proven successful for representing the spatial distribution of rainfall over conventional methods. For example, Mondal et al. (2018) showed successful applicability of TRMM Multisatellite Precipitation Analysis (TMPA) data in climate and hydrological studies. However, a similar product (TRMM2A25-V7) in Northeast Indian region largely underestimated rainfall when validated witha dense rain gauge network (Terao et al., 2017). INSAT-3D derived rainfall by Hydro-Estimator Method was found to estimate heavy rainfall episodes more accurately when compared to light rain events (Mitra et al., 2018). Global Precipitation Measurement is a new data source and provides relatively higher spatial $\left(0.1^{\circ} \mathrm{x} 0.1^{\circ}\right)$ and temporal $(30 \mathrm{~min})$ resolution for hydroclimatological studies (Skofronick-Jackson et al., 2017).

Table 1: Application of remote sensing input for hydrological studies in the Indian river basins

\begin{tabular}{|c|c|c|c|c|}
\hline \multicolumn{2}{|c|}{$\begin{array}{l}\text { S.No. Hydrological } \\
\text { Parameter }\end{array}$} & \multirow{2}{*}{$\begin{array}{l}\text { Study Area } \\
\text { Indian Monsoon Region, } \\
\text { Northeastern Indian Subcontinent }\end{array}$} & \multirow{2}{*}{$\begin{array}{l}\text { Satellite Data Used } \\
\text { INSAT, TRMM, IMR, IMERG }\end{array}$} & \multirow{2}{*}{$\begin{array}{l}\text { Reference } \\
\text { Terao et al. (2017), Mitra et al. (2018), } \\
\text { Shah and Mishra (2015) }\end{array}$} \\
\hline 1 & Precipitation & & & \\
\hline 2 & Snow Cover & $\begin{array}{l}\text { Indian Himalayan Glaciers, Pindari } \\
\text { glacier, Himalayan River Basin }\end{array}$ & $\begin{array}{l}\text { TanDEM-X InSAR, GRACE, } \\
\text { Landsat Imagery, MODIS, } \\
\text { Sentinel-1 }\end{array}$ & $\begin{array}{l}\text { Wulf et al. (2016), } \\
\text { Pandey et al. (2018), } \\
\text { Snapir et al. (2019) }\end{array}$ \\
\hline 3 & $\begin{array}{l}\text { Evapotrans- } \\
\text { piration }\end{array}$ & Kangsabati Basin, Ganga Basin & MODIS & $\begin{array}{l}\text { Srivastava et al. (2017), } \\
\text { Shah and Mishra (2016) }\end{array}$ \\
\hline 4 & Soil Moisture & $\begin{array}{l}\text { Bundelkhand Region, Indian } \\
\text { Subcontinent }\end{array}$ & MODIS, SMOS, & $\begin{array}{l}\text { Padhee et al. (2017), Varikoden and } \\
\text { Revadekar (2018), Patil and } \\
\text { Ramsankaran (2018) }\end{array}$ \\
\hline 5 & $\begin{array}{l}\text { Water Level } \\
\text { and Ground } \\
\text { water storage }\end{array}$ & $\begin{array}{l}\text { North-West India, Ganga- } \\
\text { Brahmaputra, Godavari, Krishna } \\
\text { and Mahanadi Basin,Western and } \\
\text { Southern Part of India,Kosi River } \\
\text { Basin }\end{array}$ & $\begin{array}{l}\text { GRACE, ENVISAT, AVHRR, } \\
\text { MODIS, Jason-2, TRMM, } \\
\text { AMSR-E, AMSR-2 }\end{array}$ & $\begin{array}{l}\text { Bhanja et al. (2017), } \\
\text { Mukherjee et al. (2018a), } \\
\text { Chembolu et al. (2018) }\end{array}$ \\
\hline 6 & Water Quality & Brahmani Basin, Beas Basin, & MODIS, Landsat- 8 & $\begin{array}{l}\text { Swain and Sahoo (2017), } \\
\text { Kumar et al. (2016b) }\end{array}$ \\
\hline
\end{tabular}

*TRMM - Tropical Rainfall Measurement Mission, IMR - INSAT Multi-spectral rainfall, IMERG -Integrated Multisatellite Retrievals for GPM, GPM - Global Precipitation Measurement, GRACE - Gravity Recovery And Climate Experiment, MODIS - Moderate Resolution Imaging Spectroradiometer, ENVISAT - Environmental Satellite, AVHRR - Advanced Very High Resolution Radiometer, AMSR - Advanced Microwave Scanning Radiometer 


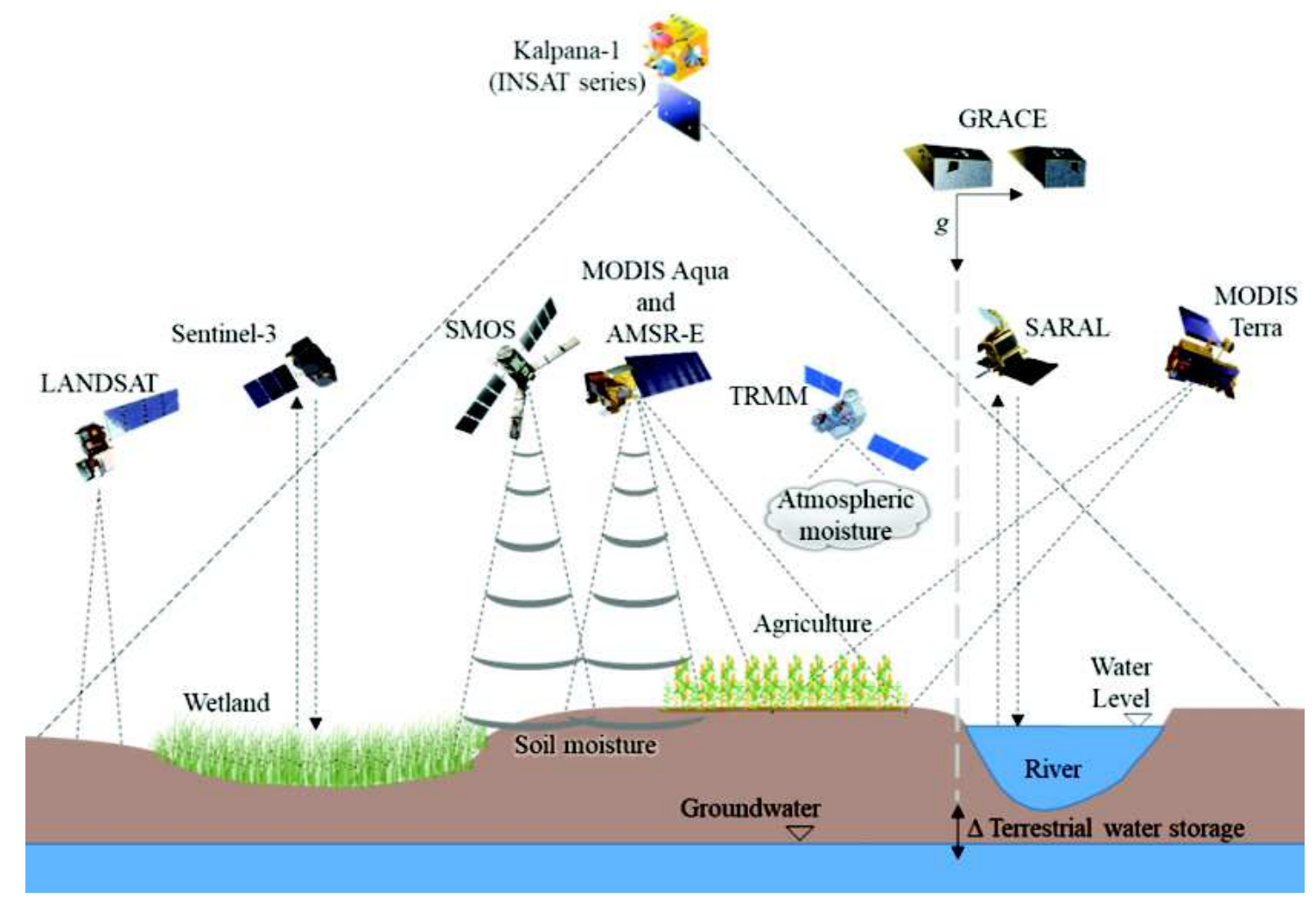

Fig. 2: Active satellites of the present decade (2010-2020) used in different fields of hydrology

\section{Snow and Ice Cover Mapping}

In the global hydrological cycle, snow and glaciers hold one-sixth of water and are a key environmental indicator for both local and global climate change. AWIFS, MODIS, LISS, Landsat, Sentinel and DEM products like ASTER, Cartosat and SRTM are the different dataset used for mapping snow cover and glacier mass changes (Behera et al., 2018; Gaddam et al., 2016; Joshi et al., 2018; Mukherjee et al., 2018b; Varade and Dikshit, 2019). Using data from MODIS Terra, Shukla et al. (2017) mapped snow cover variability and estimated its relationship with topographical features in the Satluj River basin. Pandey et al. (2018) identified the snow area and snout point for different years by using a series of multi-date Lands at imagery with manual digitization. Snapir et al. (2019) produced monthly maps of dry and wet snow areas by applying data fusion techniques to MODIS fractional snow cover and Sentinel-1 wet snow mask. A distributed hydrological model applied in the Sutlej Valley showed $45 \%$ of snow and glacier contribution to annual discharge of the river at the mountain front revealing the importance of snow melting runoff (Wulf et al., 2016).

\section{Evapotranspiration}

In the global water cycle, evapotranspiration (ET) affects the climate feedback mechanism and availability of freshwater resources. ET can be estimated using satellite inputs either by energy balance methods (eg. SABEL, 3T-Model, etc.) or hydrological models (eg. VIC, SWAT, etc.). A comparative analysis between ET estimates of VIC3L model and MODIS sensor, with Penman-Monteith based in-situ ET estimates revealed underestimation of MODIS-ET values due to cloud cover and leaf shadowing effects (Srivastava et al., 2017). Using in-situ and satellite based observations and the VIC model with an irrigation scheme, it was showed that the presence of irrigation substantially alters water budget and land surface temperature (LST) in the sub-continental river basins like Indus and Ganga basin (Shah et al., 2019).

\section{Soil Moisture}

Soil moisture plays a crucial role in the partitioning of rainfall into runoff and infiltration, thus eventually affecting ET and groundwater recharge. Hence, any 
error in the simulation of soil moisture by hydrologic models, due to errors in rainfall observations, soil hydraulic parameters or structural error in process representation, would affect streamflow simulations. Patil and Ramsankaran (2017 and 2018) implemented an EnKF based assimilation of SMOS soil moisture to study the improvements in streamflow simulations of SWAT model in Munneru catchment of the Krishna River basin. Although they found that improvements in streamflow simulations are only moderate, probably due to errors in other model inputs and/or model structure, the method demonstrates significant potential for large-scale implementation of real-time hydrologic model simulations for the entire country.

A time-based function of space-borne soil moisture proposed by Padhee et al. (2017) was found to have a better association with crop yield than vegetation based indices in arid and semi-arid areas of Bundelkhand region in Indiadue to the direct influence of soil moisture in irrigated and rainfed conditions. Soil moisture can also be used as an efficient indicator in the hydrology because of its strong association with rainfall. This association was explained by Varikoden and Revadekar (2018) using a soil moisture product derived from four passive and two active microwave sensors spanning over the period 1979-2013 from the European Space Agencyand gridded daily rainfall data from the Indian Meteorological Department.

\section{Ground Water Storage and Water Level}

Groundwater is a vital resource to sustain agricultural, industrial, and domestic activities inpopulated countries like India or arid regions (Middle East and North Africa). It is also an important component of the global water cycle. Chembolu et al. (2018) successfully used altimetry based water level data to develop wetland storage-elevation curves and to improve understanding of river-flood plain wetland interactions for the Kosi River. Bhanja et al. (2017) found that a shift in groundwater withdrawal pattern and management practices for sustainable water utilization appeared to slow recharge to aquifers.

\section{Development of in-situ Observational Techniques}

Collection of in-situ data adopting traditional methods is often expensive and time consuming, for example, bathymetry data of water bodies such as tanks and reservoirs. Although bathymetry data of some large reservoirs are available to derive the stage-storage relationships, often such data are not available for large irrigation tanks and lakes which play a significant role in the hydrology of the basin. Hence, modelling the hydrology of such systems with limited data involves large uncertainties. Young et al. (2017) developed and demonstrated a small, low-cost robotassisted surface data collection method at three different sites within the Arkavathy Basin located near Bangalore, Karnataka. Further, an automated workflow to integrate high-resolution bathymetry data through photogrammetry from the Unmanned Aerial Vehicle (UAV) over dry regions of the tank bed and the bathymetry of the submerged portions derived from the Unmanned Surface Vehicle (USV) using sonar sensors was evaluated. The study showed that apart from being low cost, this technology enables collecting highly accurate data rapidly for large regions to improve the hydrologic understanding and modelling of highly human impacted watersheds.

\section{Uncertainty Modeling}

Hydrologic modelling is burdened with uncertainties at several levels. Even when the model is physically consistent with the processes occurring at different spatial and time scales, its application in a given context typically requires model calibration and validation, both of which introduce uncertainties due to parameter uncertainty. Limitations due to quality and quantity of data - which is rather unfortunately common in the Indian context - render the model parameters particularly uncertain. The processes such as evapotranspiration, streamflow, infiltration and groundwater recharge are modelled differently in different hydrologic models and thus may result in varying inferences. Additionally, when the hydrologic models are used to draw inferences about how the hydrologic future is likely to unfold under climate change, uncertainties introduced by scale mismatch between the global climate models (GCMs) providing the climate projections and the processes modelled by the hydrologic models, along with the climate change scenarios used in arriving at the climate projections introduce a significant uncertainty. Quantifying such uncertainties has been a major thrust of research in the country in the last about five years.

Chawla and Mujumdar (2018) used the VIC 
model to segregate the contribution to overall uncertainty in hydrologic projections from GCMs, emission scenarios, land use scenarios, stationarity assumption of the hydrologic model, and internal variability of the processes, with Upper Ganga Basin (UGB). For modelling urban floods, IntensityDuration-Frequency (IDF) relationships are often used to obtain precipitation intensity. Change in IDF relationship due to climate change (and other forcings) will affect hydrologic designs to mitigate the impacts of floods. Estimation of such change needs to account for the significant uncertainty due to the choice of climate models, scenarios and parameters of the extreme value distributions.Chandra and Mujumdar (2018) used a Bayesian hierarchical model to obtain spatial maps and to quantify the associated uncertainties in the return levels of precipitation extremes in urban areas.

Climate change poses serious implications for the water resource in the Indian sub-continent. Majority of the sub-continental river basins in the country are projected to witness wetter and warmer climate in the 21 st century thereby affecting wateravailability in the region (Mishra and Lilhare, 2016). In addition to climate change, changes in land use/ land cover alter the hydrologic cycle and ultimately impact water resources. Hydrological model simulations may have uncertainties due to model structure, model parameters, and model input data.

\section{References}

Ahada C P S and Suthar S (2018) A GIS based DRASTIC model for assessing aquifer vulnerability in Southern Punjab, India Modeling Earth Systems and Environment 4 635-645

Ali S A, Aadhar S, Shah H L and Mishra V (2018) Projected increase in Hydropower production in India under climate change Sci Rep $\mathbf{8} 12450$

Anand J, Gosain A K, Khosa R and Srinivasan R (2018a) Regional scale hydrologic modeling for prediction of water balance, analysis of trends in streamflow and variations in streamflow: The case study of the Ganga River basin $J$ Hydrol Reg Stud 16 32-53 https://doi.org/10.1016/ j.ejrh.2018.02.007

Anand J, Gosain A K and Khosa R (2018b) Prediction of land use changes based on Land Change Modeler and attribution of changes in the water balance of Ganga basin to land use
Several methods exist in the literature for modeling the uncertainty in projections from a hydrological model. For example, uncertainty analysis (parameter and model predictive uncertainty) of the simulations from the SWAT model has been done using Sequential Uncertainty Fitting (SUFI-2)).

\section{Concluding Remarks}

The increasing availability of hydro-climatic datasets in the last few years has seen tremendous growth in the number of studies on modeling of hydrological processes in medium sized to large river basins. Efforts have also been made to develop hydrological models that are tailor-made to datasets and hydro-climatic conditions in Indian basins, which should be further consolidated. Modeling studies still need to overcome the challenges of incorporating snow/glacial melt processes, non-stationarity, and anthropogenic influences. Strong efforts are also needed to develop socio-hydrological models across a range of socioeconomic and hydrological settings to address the needs of a diverse society. As advances in hydrology depend strongly on observations, development of lowcost sensors and crowd sourcing approaches for data retrieval need to be further explored. Finally, understanding the diversity of eco-hydrological processes and surface-groundwater interactions across the country should be aided via development of critical zone observatories across a hydro-climatic gradient.

change using the SWAT model Sci Total Environ 644 503519

Asoka A, Gleeson T, Wada Y and Mishra V (2017) Relative contribution of monsoon precipitation and pumping to changes in groundwater storage in India Nat Geosci 10 109-117

Bagalkot N and Kumar G S (2016) Numerical modeling of two species radionuclide transport in a single fracturematrix system with variable fracture aperture Geosci $J \mathbf{2 0} 627$ 638

Banwart S, Chorover J, Gaillardet J, Sparks D, White T, Anderson S, Aufdenkampe A, Bernasconi S, Brantley S and Chadwick O (2013) Sustaining Earth's critical zone basic science and interdisciplinary solutions for global challenges (https:// www.czen.org/sites/default/files/Sustaining-EarthsCritical-Zone_FINAL-290713.pdf ) University of 
Sheffield, Sheffield1-48

Beegum S, Šimunek J, Szymkiewicz A, Sudheer K and Nambi I M (2018) Implementation of Solute Transport in the Vadose Zone into the "HYDRUS Package for MODFLOW" Groundwater n.a.

Behera M, Tripathi P, Das P, Srivastava S, Roy P, Joshi C, Behera P, Deka J, Kumar P and Khan M (2018) Remote sensing based deforestation analysis in Mahanadi and Brahmaputra river basin in India since 1985 J Environ Manage 206 1192-1203

Bhanja S N, Mukherjee A, Rodell M, Wada Y, Chattopadhyay S, Velicogna I, Pangaluru K and Famiglietti J S (2017) Groundwater rejuvenation in parts of India influenced by water-policy change implementation Sci Rep 77453

Bisht D S, Chatterjee C, Kalakoti S, Upadhyay P, Sahoo M and Panda A (2016) Modeling urban floods and drainage using SWMM and MIKE URBAN: a case study Nat Hazards 84 749-776

Bollasina MA, Ming Y and Ramaswamy V (2011) Anthropogenic aerosols and the weakening of the South Asian summer monsoon Science 334 502-505

Chandra R and Mujumdar P (2018) Dependence structure of urban precipitation extremes Adv Water Resour 121 206218

Chawla I and Mujumdar P P (2015) Isolating the impacts of land use and climate change on streamflow Hydrol Earth Syst Sci doi: 10.5194/hess-19-3633-2015

Chawla I and Mujumdar P (2018) Partitioning uncertainty in streamflow projections under nonstationary model conditions Adv Water Resour 112 266-282

Chembolu V, Dubey A K, Gupta P K, Dutta S and Singh R P (2018) Application of Satellite Altimetry in Understanding River-Wetland Flow Interactions of Kosi River $J$ Earth Syst Sci

Chouksey A, Lambey V, Nikam B, Aggarwal S and Dutta S (2017) Hydrological modelling using a rainfall simulator over an experimental hillslope plot Hydrology 417 (in print)

Devanand A, Roxy M K and Ghosh S (2018) Coupled LandAtmosphere Regional Model Reduces Dry Bias in Indian Summer Monsoon Rainfall Simulated by CFSv2 Geophys Res Lett 45 2476-2486

Dey P and Mishra A (2017) Separating the impacts of climate change and human activities on streamflow: A review of methodologies and critical assumptions J Hydrol 548278 290

Dominguez F, Kumar P, Liang X-Z and Ting M (2006) Impact of atmospheric moisture storage on precipitation recycling $J$
Clim 19 1513-1530

Dunlop G, Palanichamy J, Kokkat A, James E and Palani S (2019) Simulation of saltwater intrusion into coastal aquifer of Nagapattinam in the lower cauvery basin using SEAWAT Groundwater Sustainable Dev 8 294-301

Eltahir E A and Bras R L (1996) Precipitation recycling Rev Geophys 34 367-378

Gaddam V K, Sharma P, Patel L K, Meloth T and Singh A (2016) Analysis of spatio-temporal variations in snow cover over Western Himalaya. In: Land Surface and Cryosphere Remote Sensing III (Eds: Khanbilvardi R, Ganju A, Rajawat A S and Chen J M) 98772A, SPIE - International Society For Optics and Photonics

Geetha Manjari K and Sivakumar Babu G (2018) Probabilistic analysis of groundwater and radionuclide transport model from near surface disposal facilities Georisk: Assessment and Management of Risk for Engineered Systems and Geohazards 12 60-73

Ghosh S and Katkar S (2012) Modeling uncertainty resulting from multiple downscaling methods in assessing hydrological impacts of climate change Water Resour Manag 26 3559-3579

Ghosh T and Kanchan R (2016) Aquifer vulnerability assessment in the Bengal alluvial tract, India, using GIS based DRASTIC model Modeling Earth Systems and Environment 2153

Gopinath S, Srinivasamoorthy K, Saravanan K, Suma C, Prakash R, Senthilnathan D, Chandrasekaran N, Srinivas Y and Sarma V (2016) Modeling saline water intrusion in Nagapattinam coastal aquifers, Tamilnadu, India Modeling Earth Systems and Environment 22

Goyal M K, Panchariya V K, Sharma A and Singh V (2018) Comparative assessment of SWAT model performance in two distinct catchments under various DEM scenarios of varying resolution, sources and resampling methods Water Resour Manag 32 805-825

Hengade N and Eldho T (2016) Assessment of LULC and climate change on the hydrology of Ashti Catchment, India using VIC model J Earth Syst Sci 125 1623-1634

Himanshu S K, Pandey A and Shrestha P (2017) Application of SWAT in an Indian river basin for modeling runoff, sediment and water balance Environ Earth Sci 763

Joshi P and Gupta P K (2018) Assessing Groundwater Resource Vulnerability by Coupling GIS-Based DRASTIC and Solute Transport Model in Ajmer District, Rajasthan $J$ Geol Soc India 92 101-106

Joshi P P, Singh S, Rathore B, Bahuguna I and Kumar R (2018) 
Effect of Forest Fire on Snow Reflectance in Uttarakhand Region: An Analysis Using AWiFS and INSAT-3D Data $J$ Indian Soc Remote Sens 46 2107-2111

Karan S K, Samadder S R and Singh V (2018) Groundwater vulnerability assessment in degraded coal mining areas using the AHP-Modified DRASTIC model Land Degrad Dev 29 2351-2365

Kumar K K, Rajagopalan B and Cane MA(1999) On the weakening relationship between the Indian monsoon and ENSO Science $2842156-2159$

Kumar P, Thakur P K, Bansod B K and Debnath S K (2016a) Assessment of the effectiveness of DRASTIC in predicting the vulnerability of groundwater to contamination: a case study from Fatehgarh Sahib district in Punjab, India Environ Earth Sci 75879

Kumar R, Mishra V, Buzan J, Kumar R, Shindell D and Huber M (2017b) Dominant control of agriculture and irrigation on urban heat island in India Sci Rep 714054

Kumar V, Sharma A, Chawla A, Bhardwaj R and Thukral A K (2016b) Water quality assessment of river Beas, India, using multivariate and remote sensing techniques Environ Monit Assess 188137

Lathashri U and Mahesha A (2015) Simulation of saltwater intrusion in a coastal aquifer in Karnataka, India Aquat Procedia 4 700-705

Long D, Chen X, Scanlon B R, Wada Y, Hong Y, Singh V P, Chen Y, Wang C, Han Z and Yang W (2016) Have GRACE satellites overestimated groundwater depletion in the Northwest India Aquifer? Sci Rep 624398

Madhusoodhanan C, Sreeja K and Eldho T (2016) Climate change impact assessments on the water resources of India under extensive human interventions Ambio 45 725-741

Maheswaran R, R Khosa, A K Gosain, S Lahari, S K Sinha, B R Chahar and C T Dhanya (2016) Regional scale groundwater modelling study for Ganga River basin Journal of Hydrology $541727-74$

Maity S, Satyanarayana A, Mandal M and Nayak S (2017) Performance evaluation of land surface models and cumulus convection schemes in the simulation of Indian summer monsoon using a regional climate model Atmos Res 197 21-41

Mandal S P and Chakrabarty A (2016) Flash flood risk assessment for upper Teesta river basin: using the hydrological modeling system (HEC-HMS) software Modeling Earth Systems and Environment 259

Mishra V, Aadhar S, Asoka A, Pai S and Kumar R (2016) On the frequency of the 2015 monsoon season drought in the
Indo-Gangetic Plain Geophys Res Lett 43 102-12,112

Mishra V and Lilhare R (2016) Hydrologic sensitivity of Indian sub-continental river basins to climate change Global Planet Change 139 78-96

Mishra V, Shah R, Azhar S, Shah H, Modi P and Kumar R (2018) Reconstruction of droughts in India using multiple landsurface models (1951-2015) Hydrol Earth Syst Sci 22 22692284

Mishra V, Shah R and Thrasher B (2014) Soil moisture droughts under the retrospective and projected climate in India $J$ Hydrometeorol 15 2267-2292

Mitra A, Kaushik N, Singh A K, Parihar S and Bhan S (2018) Evaluation of INSAT-3D satellite derived precipitation estimates for heavy rainfall events and its validation with gridded GPM (IMERG) rainfall dataset over the Indian region Remote Sens Appl: Soc Environ 9 91-99

Mittal N, Bhave A G, Mishra A and Singh R (2016) Impact of human intervention and climate change on natural flow regime Water Resour Manage 30 685-699

Mohanadhas B and Govindarajan S K (2018) Modeling the sensitivity of hydrogeological parameters associated with leaching of uranium transport in an unsaturated porous medium Environ Eng Res 23 462-473

Mondal A, Lakshmi V and Hashemi H (2018) Intercomparison of trend analysis of multisatellite monthly precipitation products and gauge measurements for river basins of India J Hydrol 565 779-790

Mondal A, Narasimhan B, Sekhar M and Mujumdar P P (2016) Hydrologic Modelling Proc Indian Natl Sci Acad 82817 832

Montanari A, Young G, Savenije H, Hughes D, Wagener T, Ren L, Koutsoyiannis D, Cudennec C, Toth E and Grimaldi S (2013) "Panta Rhei-everything flows": change in hydrology and society - the IAHS scientific decade 20132022 Hydrol Sci J 58 1256-1275

Mukherjee A, Bhanja S N and Wada Y (2018a) Groundwater depletion causing reduction of baseflow triggering Ganges river summer drying Sci Rep 812049

Mukherjee K, Bhattacharya A, Pieczonka T, Ghosh S and Bolch $\mathrm{T}$ (2018b) Glacier mass budget and climate reanalysis data indicate a climatic shift around 2000 in Lahaul-Spiti, western Himalaya Clim Change 148 219-233

Nair A and Indu J (2016) Enhancing Noah land surface model prediction skill over Indian subcontinent by assimilating SMOPS blended soil moisture Remote Sens 8976

Niroula S, Halder S and Ghosh S (2018) Perturbations in the initial soil moisture conditions: Impacts on hydrologic 
simulation in a large river basin J Hydrol 561 509-522

Padhee S K, Nikam B R, Dutta S and Aggarwal S P (2017) Using satellite-based soil moisture to detect and monitor spatiotemporal traces of agricultural drought over Bundelkhand region of India GI Sci Remote Sens 54 144166

Pandey A, Sarkar M S, Kumar M, Singh G, Lingwal S and Rawat J S (2018) Retreat of Pindari glacier and detection of snout position using remote sensing technology Remote Sens Appl: Soc Environ 11 64-69

Pandey B K, Gosain A, Paul G and Khare D (2017) Climate change impact assessment on hydrology of a small watershed using semi-distributed model Appl Water Sci 7 2029-2041

Pathak A, Ghosh S, Kumar P and Murtugudde R (2017a) Role of oceanic and terrestrial atmospheric moisture sources in intraseasonal variability of Indian summer monsoon rainfall Sci Rep 712729

Pathak A, Ghosh S, Martinez J A, Dominguez F and Kumar P (2017b) Role of oceanic and land moisture sources and transport in the seasonal and interannual variability of summer monsoon in India J Clim 30 1839-1859

Patil A and Ramsankaran R (2017) Improving streamflow simulations and forecasting performance of SWAT model by assimilating remotely sensed soil moisture observations J Hydrol 555 683-696

Patil A and Ramsankaran R (2018) Improved streamflow simulations by coupling soil moisture analytical relationship in EnKF based hydrological data assimilation framework Adv Water Resour 121 173-188

Paul P K, Gaur S, Kumari B, Panigrahy N, Mishra A and Singh R (2019) Diagnosing Credibility of a Large-Scale Conceptual Hydrological Model in Simulating Streamflow J Hydrol Eng 2404019004

Paul P K, Kumari N, Panigrahi N, Mishra A and Singh R (2018a) Implementation of cell-to-cell routing scheme in a large scale conceptual hydrological model Environ Modell Software 101 23-33

Paul S, Ghosh S, Oglesby R, Pathak A, Chandrasekharan A and Ramsankaran R (2016) Weakening of Indian summer monsoon rainfall due to changes in land use land cover $S c i$ Rep 632177

Paul S, Ghosh S, Rajendran K and Murtugudde R (2018b) Moisture Supply From the Western Ghats Forests to Water Deficit East Coast of India Geophys Res Lett 45 43374344

Rai P K, Chahar B and Dhanya C (2017) GIS-based SWMM model for simulating the catchment response to flood events Hydrol Res 48 384-394

Renu V and Kumar G S (2016) Numerical modeling on benzene dissolution into groundwater and transport of dissolved benzene in a saturated fracture-matrix system Environ Processes 3 781-802

Sahana A, Pathak A, Roxy M and Ghosh S (2018) Understanding the role of moisture transport on the dry bias in indian monsoon simulations by CFSv2 Clim Dyn 52 637-651

Sahoo S and Jha M K (2017) Numerical groundwater-flow modeling to evaluate potential effects of pumping and recharge: implications for sustainable groundwater management in the Mahanadi delta region, India Hydrogeol J 25 2489-2511

Saji N, Goswami B, Vinayachandran P and Yamagata T (1999) A dipole mode in the tropical Indian Ocean Nature 401360

Sarangi C, Tripathi S N, Kanawade V P, Koren I and Pai D S (2017) Investigation of the aerosol-cloud-rainfall association over the Indian summer monsoon region Atmos Chem Phys 17 5185-5204

Sashikkumar M, Selvam S, Kalyanasundaram V L and Johnny J C (2017) GIS based groundwater modeling study to assess the effect of artificial recharge: A case study from Kodaganar river basin, Dindigul district, Tamil Nadu J Geol Soc India 89 57-64

Shah, H. L. L., and V. Mishra (2015), Uncertainty and Bias in Satellite-based Precipitation Estimates over Indian Subcontinental Basins: Implications for Real-time Streamflow Simulation and Flood Prediction J Hydrometeorol 17 (2015), 615-636, doi:10.1175/JHM-D-15-0115.1

Sekhar M (2016) Influences of climate and agriculture on water and biogeochemical cycles: Kabini critical zone observatory Proc Indian Natl Sci Acad $\mathbf{8 2}$ 833-846

Shah H L and Mishra V (2016) Hydrologic changes in Indian subcontinental river basins (1901-2012) J Hydrometeorol 17 2667-2687

Shah H L, Zhou T, Huang M and Mishra V (2019) Strong influence of irrigation on water budget and land surface temperature in Indian sub-continental river basins J Geophys Res: Atmos 124 1449-1462

Sharma P, Shukla S K, Choudhary R and Swami D (2016) Modeling for solute transport in mobile-immobile soil column experiment $J$ Hydraul Eng 22 204-211

Shukla S, Kansal M L and Jain S K (2017) Snow cover area variability assessment in the upper part of the Satluj river basin in India Geocarto Int 32 1285-1306

Singh V (2015) The Indian critical zone - A case for priority 
studies Curr Sci 108 1045-1046

Sishodia R P, Shukla S, Graham W D, Wani S P, Jones J W and Heaney J (2017) Current and future groundwater withdrawals: Effects, management and energy policy options for a semi-arid Indian watershed $A d v$ Water Resour $110459-475$

Sivapalan M, Takeuchi K, Franks S, Gupta V, Karambiri H, Lakshmi V, Liang X, McDonnell J, Mendiondo E and O'connell P (2003) IAHS Decade on Predictions in Ungauged Basins (PUB), 2003-2012: Shaping an exciting future for the hydrological sciences Hydrol Sci J 48 857880

Skofronick-Jackson G, Petersen W A, Berg W, Kidd C, Stocker E F, Kirschbaum D B, Kakar R, Braun S A, Huffman G J and Iguchi $\mathrm{T}$ (2017) The global precipitation measurement (GPM) mission for science and society Bull Am Meteorol Soc 98 1679-1695

Snapir B, Momblanch A, Jain S, Waine T and Holman I P (2019) A method for monthly mapping of wet and dry snow using Sentinel-1 and MODIS: Application to a Himalayan river basin Int J Appl Earth Obs Geoinf 74 222-230

Srivastava A, Sahoo B, Raghuwanshi N S and Singh R (2017) Evaluation of variable-infiltration capacity model and MODIS-terra satellite-derived grid-scale evapotranspiration estimates in a River Basin with Tropical Monsoon-Type climatology J Irrig Drain Eng 143 04017028

Surinaidu L, Muthuwatta L, Amarasinghe U A, Jain S, Ghosh N, Kumar S and Singh S (2016) Reviving the Ganges water machine: Accelerating surface water and groundwater interactions in the Ramganga sub-basin J Hydrol $540207-$ 219

Suryavanshi S, Pandey A and Chaube U C (2017) Hydrological simulation of the Betwa River basin (India) using the SWAT model Hydrol Sci J 62 960-978

Swain R and Sahoo B (2017) Mapping of heavy metal pollution in river water at daily time-scale using spatio-temporal fusion of MODIS-aqua and Landsat satellite imageries $J$
Environ Manage 192 1-14

Terao T, Murata F, Yamane Y, Kiguchi M, Fukushima A, Tanoue M, Ahmed S, Choudhury S A, Syiemlieh H J and Cajee L (2017) Direct Validation of TRMM/PR Near Surface Rain over the Northeastern Indian Subcontinent Using a Tipping Bucket Raingauge Network SOLA 13 157-162

Varade D and Dikshit O (2019) Improved assessment of Atmospheric Water Vapor Content in the Himalayan Regions around the Kullu Valley in India using Landsat-8 data Water Resour Res 55 462-475

Varikoden H and Revadekar J (2018) Relation Between the Rainfall and Soil Moisture During Different Phases of Indian Monsoon Pure Appl Geophys 175 1187-1196

Wagh V, Panaskar D, Muley A, Mukate S and Gaikwad S (2018) Neural network modelling for nitrate concentration in groundwater of Kadava River basin, Nashik, Maharashtra, India Groundwater Sustainable Dev 7 436-445

Wagner P D, Bhallamudi S M, Narasimhan B, Kantakumar L N, Sudheer K, Kumar S, Schneider K and Fiener P (2016) Dynamic integration of land use changes in a hydrologic assessment of a rapidly developing Indian catchment $\mathrm{Sci}$ Total Environ 539 153-164

Wulf H, Bookhagen B and Scherler D (2016) Differentiating between rain, snow, and glacier contributions to river discharge in the western Himalaya using remote-sensing data and distributed hydrological modeling Adv Water Resour 88 152-169

Yadav B, Mathur S and Yadav B K (2018) Data-based modelling approach for variable density flow and solute transport simulation in a coastal aquifer Hydrol Sci J 63 210-226

Young S, Peschel J, Penny G, Thompson S and Srinivasan V (2017) Robot-assisted measurement for hydrologic understanding in data sparse regions Water 9494

Zope P, Eldho T and Jothiprakash V (2016) Impacts of land useland cover change and urbanization on flooding: A case study of Oshiwara River Basin in Mumbai, India Catena 145 142-154. 